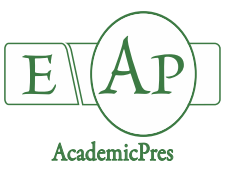

Acemi A et al. (2021)

Notulae Botanicae Horti Agrobotanici Cluj-Napoca

Volume 49, Issue 2, Article number 12296

DOI: $10.15835 /$ nbha49212296

Research Article

\title{
Molecular weight and concentration of chitosan affect plant development and phenolic substance pattern in arugula
}

\section{Arda ACEMİ*, Ece GÜN POLAT, Merve ÇAKIR, Elif DEMİRYÜREK, Bahar YAVUZ, Fazıl ÖZEN}

\begin{abstract}
Kocaeli University, Faculty of Arts and Sciences, Department of Biology, 41001 Izmit, Kocaeli, Turkey; arda.acemi@kocaeli.edu.tr(*corresponding author); ece121415@hotmail.com; meerveckr@gmail.com; elifdemiryurek000@gmail.com; baharbayrak@hotmail.com; fazil.ozen@kocaeli.edu.tr
\end{abstract}

\begin{abstract}
The present research reports the role of chitosan's molecular weight $(1,10$, and $100 \mathrm{kDa})$ on the differentiation of its effects on arugula (Eruca vesicaria ssp. sativa) cultivation in a controlled environment. The leaves' phenolic substance pattern from the plants treated with the chitosan variant that gave the best developmental results was analyzed through a reversed-phase HPLC. The leaf production was enhanced after $10 \mathrm{kDa}$ chitosan treatment at $5 \mathrm{mg} \mathrm{L}^{-1}$, while the leaf area expansion was significantly improved after 1 and 100 $\mathrm{kDa}$ chitosan at $20 \mathrm{mg} \mathrm{L}^{-1}$ and $10 \mathrm{kDa}$ chitosan at $5 \mathrm{mg} \mathrm{L}^{-1}$. The plant's rhizogenic development was restricted after all chitosan treatments regardless of their molecular weight and concentration. The contents of chlorophyll $\mathrm{b}$ and carotenoids increased after the treatments; however, chlorophyll a content was not significantly affected by the treatments and remained unchanged. The chromatographic analysis showed that $10 \mathrm{kDa}$ chitosan treatment at $5 \mathrm{mg} \mathrm{L}^{-1}$ increased gallic acid, rutin, and p-coumaric acid contents and made significant changes in the individual phenolic substance pattern. The current study indicated that direct application of chitosan to soil restricts root production in arugula but enhances foliar growth, which is beneficial to producers. On the other hand, constant- or over-treatment with chitosan could inhibit root growth and further lead to developmental deficiencies sourced by nutrient uptake disorders. The use of chitosan as an organic and natural biostimulant in controlled-environment agriculture could be a better option than synthetic growth stimulants.
\end{abstract}

Keywords: biopolymer; chitin; Eruca sativa; leaf development; phenolic pattern; rhizogenesis

\section{Introduction}

The arising problems of current agriculture and horticulture such as climate change, several biotic and abiotic stress factors, over-farming, dense urbanization, increased costs of fertilizers and other chemicals, and rising population made the researchers search for more practical, lower-cost, more efficient, and sustainable organic farming solutions that apply to relatively small places in urban environments. Vertical farms and controlled-environment agriculture practices have been suggested as potential solutions for the industry's problems, as mentioned above (Benke and Tomkins, 2018). Chemical fertilizers, growth promoters and 
regulators, and other synthetic chemicals used for disease control are being used by producers, especially in conventional production, although these substances are not preferred in horticultural plants' organic production. Therefore, there is a need for natural alternatives of growth promoters, organic fertilizers, and disease control agents in organic production maintained in controlled environments such as vertical farms to ensure a sustainable and clean production (Acemi et al., 2018).

Chitosan, the deacetylated form of one of the most abundant polymers in nature, namely chitin (Muxika et al., 2017), has been proposed to be a potential alternative to synthetic cytokinins and jasmonic acid in tissue cultures of an ornamental plant (morning glory, Ipomoea purpurea) and an orchid species with edible tubers (long-lipped Serapias, Serapias vomeracea), respectively (Acemi et al., 2018; Acemi, 2020a). Also, yieldpromotive and antioxidant-accumulative effects of chitosan were shown in strawberry fruit (Rahman et al., 2018), while a similar promotive response in growth and yield in Indian spinach was reported by Mondal et al. (2011). However, the changes in chitosan's effects in response to its chemical structure were demonstrated in several orchid species (Nge et al., 2006; Uthairatanakij et al., 2007; Acemi, 2020b). Therefore, a possible differentiation in the effects of chitosan might be seen in other plant species.

The plant growth-promoting effects, biodegradability, naturality, and low cost of chitosan might put forward the polymer as an option to be used in organic farming. To test its impact and understand its usability on leafy vegetables' cultivation in such controlled environments described above, we treated arugula plants with chitosan in varying average molecular weights. Arugula (Eruca vesicaria ssp. sativa) is a fast-growing, cool-season annual leafy vegetable from Brassicaceae (Crucifers) family. The species has pale-green and low-growing leaves with a distinct spicy-pungent flavor. The leaves of arugula are either eaten raw, used in salads, or topping on pizzas (Morales and Janick, 2002).

The most common secondary metabolites in plant tissues are phenolic compounds, ranging from basic phenolic acids to polymerized tannins with various health benefits (Kıran Acemi et al., 2020). Therefore, an increase in edible plants' phenolic substance contents after biostimulant treatments would be beneficial for producers and consumers. Therefore, phenolic substance patterns should also be investigated as natural sources for these compounds that have become popular among consumers. It should be noted that possible differences in the morphology and color of the arugula plants tested might also affect the consumers' choice (Ladaru et al., 2020). In this context, we hypothesized that besides its antimicrobial (Sahariah and Másson, 2017) and shelflife extending properties for several fruits and vegetables (Romanazzi et al., 2015), chitosan should promote or affect the growth, yield, and phenolic substance pattern of arugula plants in this study.

\section{Materials and Methods}

\section{Plant material, treatments, and cultivation conditions}

The seeds of Eruca vesicaria ssp. sativa (Mill.) Thell. (syn. Eruca sativa Mill.) cv. Elizabeth were provided from ZenGarden Seeds, Turkey. The seeds were deposited at a dark, dry, and cool place until the experiments started. The seeds were planted into peat enriched with perlite (30\%; v/v) filled in wells of 45 -well trays. The peat was provided from Mita Tarım, Turkey. According to the producer's statements, the N-P-K composition and $\mathrm{pH}$ of the peat were $14-16-18\left(0.6 \mathrm{~kg} \mathrm{~N}-\mathrm{P}-\mathrm{K} \mathrm{per}^{3}\right)$ and between 5.5 and 6.5 , respectively. The trays with seeds were irrigated with distilled water and then covered with cling film for the first 3 days of the cultivation. The plants were then treated with shrimp shell waste-originated chitosan samples that were previously produced, characterized, and provided by the Institute of Plant Biology and Biotechnology, University of Münster, Münster, Germany. The chitosan samples that had an acetylation degree (DA) of 10\% and average molecular weight of 1,10 , and $100 \mathrm{kDa}$ were applied at 5,10 , and $20 \mathrm{mg} \mathrm{L}^{-1}$ concentrations in an aqueous solution prepared with distilled water. The cultures were irrigated once in two days with $10 \mathrm{ml}$ of distilled water, while the chitosan treatments were applied at the same volume once per week instead of distilled water irrigation. The trays were kept on vertically arranged racks with individual illumination systems that provided 
$80 \mu \mathrm{mol} \mathrm{m}{ }^{-2} \mathrm{~s}^{-1}$ photosynthetic photon flux density with a 16 -h photoperiod. The cultures were maintained in an air-conditioned plant growth room at $20 \pm 1{ }^{\circ} \mathrm{C}$.

\section{Photosynthetic pigment quantification}

Leaf samples were dried using a freeze dryer for $24 \mathrm{~h}$ (Alpha 1-2 LD plus, Martin Christ, Osterode, Germany) before the extraction process. Two hundred mg leaf sample was extracted using absolute acetone (10 $\mathrm{ml}$ ), and the extract was centrifuged at $6000 \mathrm{rpm}$ for $10 \mathrm{~min}$ at $4{ }^{\circ} \mathrm{C}$. The supernatant was then collected, and the absorbance at 661.6, 644.8, and $420 \mathrm{~nm}$ was measured using a spectrophotometer (Cary 60, Agilent, CA, USA). Chlorophyll a $\left(\mathrm{C}_{\mathrm{a}}\right), \mathrm{b}\left(\mathrm{C}_{\mathrm{b}}\right)$, and total carotenoid $\left(\mathrm{C}_{\mathrm{x}+\mathrm{c}}\right)$ quantities were calculated using the equation (1) described by Lichtenthaler (1987). The data were expressed as $\mu \mathrm{g} \mathrm{ml}^{-1}$ extract.

(1) $\mathrm{C}_{\mathrm{a}}=11.24 A_{661.6}-2.04 A_{644.8}$

$\mathrm{C}_{\mathrm{b}}=20.13 A_{644.8}-4.19 A_{661.6}$

$\mathrm{C}_{\mathrm{x}+\mathrm{c}}=\left(1000 A_{420}-1.90 C_{\mathrm{a}}-63.14 C_{\mathrm{b}}\right) / 214$

\section{Leaf area calculation}

The leaves were collected after the other calculations were done, and their areas were measured following the millimeter graph paper method of Pandey and Singh (2011). Briefly, the method calculates the leaf area $\left(\mathrm{cm}^{2}\right)$ by dividing the weight $(\mathrm{g})$ of the area covered by the leaf outline on a millimeter graph paper to the weight of one $\mathrm{cm}^{2}$ of the same graph paper.

\section{Quantification of individual phenolic substances}

The method of Kiran Acemi et al. (2020) was followed to extract phenolic substances from leaves. The leaf samples were harvested from the plant with the best foliar growth in response to the chitosan treatment. The leaves harvested were dried using the freeze dryer for $24 \mathrm{~h}$, and then they were ground into a fine powder. One gram of leaf powder was placed in a conical flask, and it was extracted with $20 \mathrm{~mL}$ of $70 \%$ (v:v) aqueous ethanol in an ultrasonic ( $300 \mathrm{~W}, 50 \mathrm{kHz}$ ) bath (ISOLAB, Eschau, Germany) at $50^{\circ} \mathrm{C}$ for $40 \mathrm{~min}$. The resulting crude extract was collected and centrifuged at $4400 \times \mathrm{g}$ for $10 \mathrm{~min}$, and then the supernatant was collected and filtered through a $0.22 \mu \mathrm{m}$ syringe filter. Analysis of individual phenolic compounds was made through a highperformance liquid chromatography (HPLC) instrument (Shimadzu, Kyoto, Japan) equipped with an SCL$10 \mathrm{~A}$ vp system controller, DGU-14A degasser, LC-10AD vp pump, SIL-10AD vp autosampler, CTO-10A vp column oven, and SPDM-10A photodiode array detector $\left(\lambda_{\max }=278 \mathrm{~nm}\right)$. A reverse-phase column Eclipse XDB-C18 ( $250 \mathrm{~mm} \times 4.6 \mathrm{~mm}, 5 \mu \mathrm{m}$ particle size; Agilent, CA, USA) was used for chromatographic analysis. The flow rate was set to $0.8 \mathrm{ml} \mathrm{min}{ }^{-1}$, while the column temperature was $30^{\circ} \mathrm{C}$. The results were expressed as ppm.

\section{Statistical analysis}

Two seeds were sown into each well, and each repeat consisted of 30 plants. The experiments were repeated thrice, and thereby each treatment was tested on 90 arugula plants. The developmental parameters' measurement and phenolic substance quantification were done at the end of the cultivation period of $45 \mathrm{~d}$. The means were compared through Duncan's multiple range test (MRT) following analysis of variance (ANOVA) or independent samples $t$-test at a significance level of $\mathrm{p}<0.05$, where appropriate. IBM SPSS Statistics software, version 22 , was used for statistical analyses. The data were represented as "mean value \pm standard deviation (SD)". The morphometric results' relationship was analyzed through hierarchical cluster analysis (HCA) based on the Euclidean distance and complete-linkage clustering method. The clustering heatmap was created through ClustVis (Metsalu and Vilo, 2015). 


\section{Results}

\section{Effect of chitosan on leaf development}

Leaf development parameters in arugula plants were significantly affected in response to chitosan treatments (Figure 1).
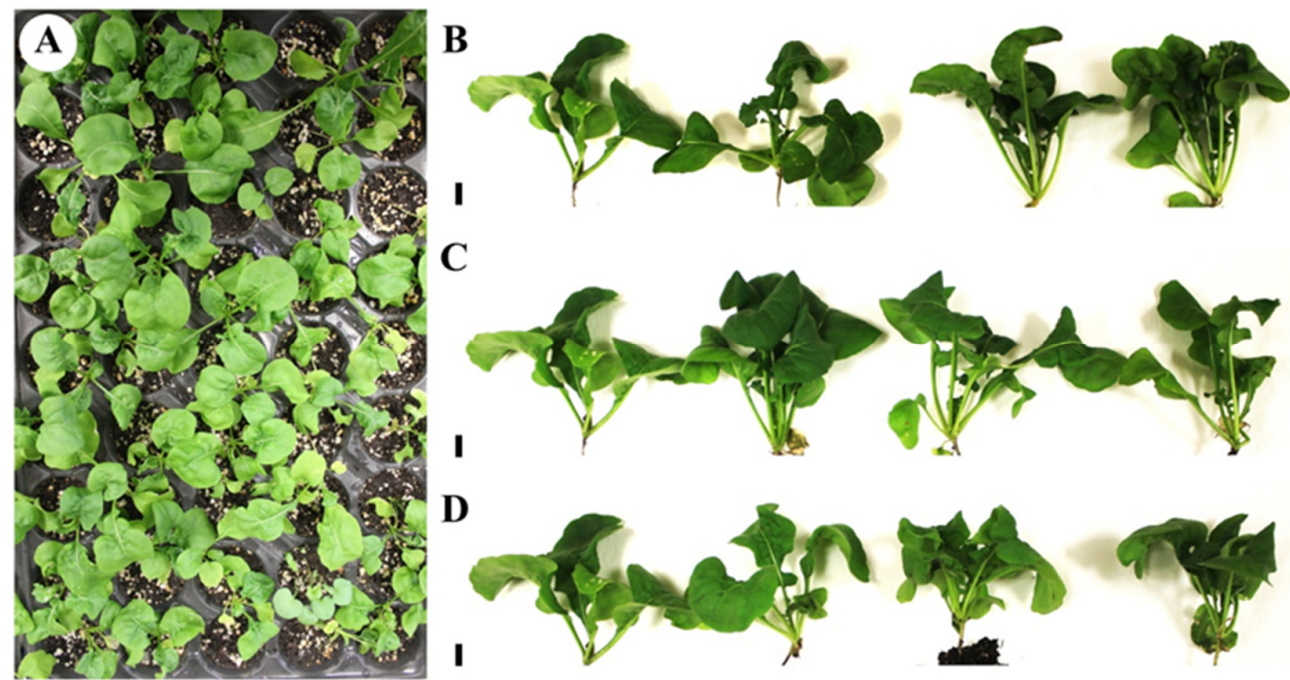

Figure 1. The general appearance of a cultivation set (A) and comparison of the arugula leaves harvested from the cultures treated with $1(\mathrm{~B}), 10(\mathrm{C})$, and $100 \mathrm{kDa}(\mathrm{D})$ chitosan

The plants aligned from left to right were harvested from the control group and the treatment groups irrigated with chitosan variants at 5,10 , and $20 \mathrm{mg} \mathrm{L}^{-1}$ concentrations. The scale bars represent $1 \mathrm{~cm}$. The brightness and contrast of images were adjusted for the sake of clarity

The plants grown in the control group produced $6.05 \pm 0.96$ leaves per plant. The maximum number of leaves per plant $(6.72 \pm 0.66)$ were counted from the plants irrigated with water having $10 \mathrm{kDa}$ chitosan at $5 \mathrm{mg} \mathrm{L}^{-1}$, whereas the irrigation water with $100 \mathrm{kDa}$ chitosan at $5 \mathrm{mg} \mathrm{L}^{-1}$ reduced the leaf production and gave the minimum leaf number $(4.99 \pm 0.71)$. A concentration-dependent decrease in leaf number was found after $10 \mathrm{kDa}$ chitosan treatments. However, $100 \mathrm{kDa}$ chitosan treatments increased leaf production in the same way (Figure 2).

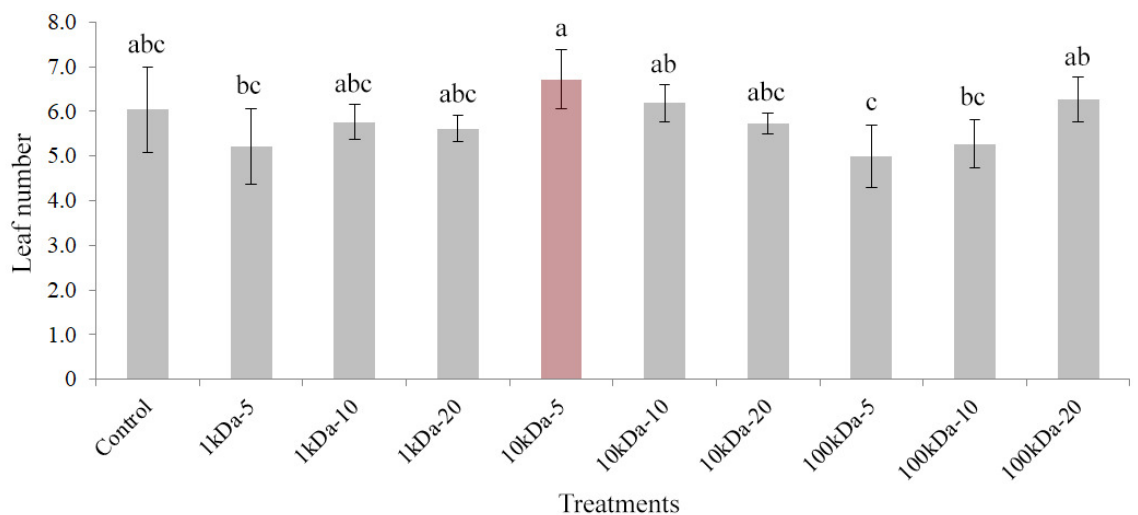

Figure 2. Effects of chitosan at 1, 10, and $100 \mathrm{kDa}$ molecular weights on the leaf production in arugula The treatments are represented as "chitosan's MW - concentration $\left(\mathrm{mg} \mathrm{L}^{-1}\right)$ ". The bars with the same superscript letters are not significantly different by Duncan's multiple range test $(\mathrm{p}<0.05)$ 
Chitosan treatments greatly influenced leaf expansion. Also, the molecular weight and concentration of chitosan played a role in the diversification of its effects in expanding arugula plants' leaves. The plants' leaves from the control group had an average of $5.68 \pm 0.57 \mathrm{~cm}^{2}$ area per leaf. The treatments of 1,10 , and $100 \mathrm{kDa}$ chitosan at 20,5 , and $20 \mathrm{mg} \mathrm{L}^{-1}$, respectively, induced statistically the same leaf expansion values. The maximum leaf area $\left(6.72 \pm 0.25 \mathrm{~cm}^{2}\right)$ was found from the leaves of the arugula plants irrigated with the solution including $10 \mathrm{kDa}$ chitosan at $5 \mathrm{mg} \mathrm{L}^{-1}$, whereas the $1 \mathrm{kDa}$ chitosan treatment at $5 \mathrm{mg} \mathrm{L}^{-1}$ resulted in minimum leaf expansion $\left(4.55 \pm 0.22 \mathrm{~cm}^{2}\right)$ in the plants (Figure 3). A similar concentration-dependent change in the growth parameter with leaf production and root elongation was also observed in the leaf expansion parameter.

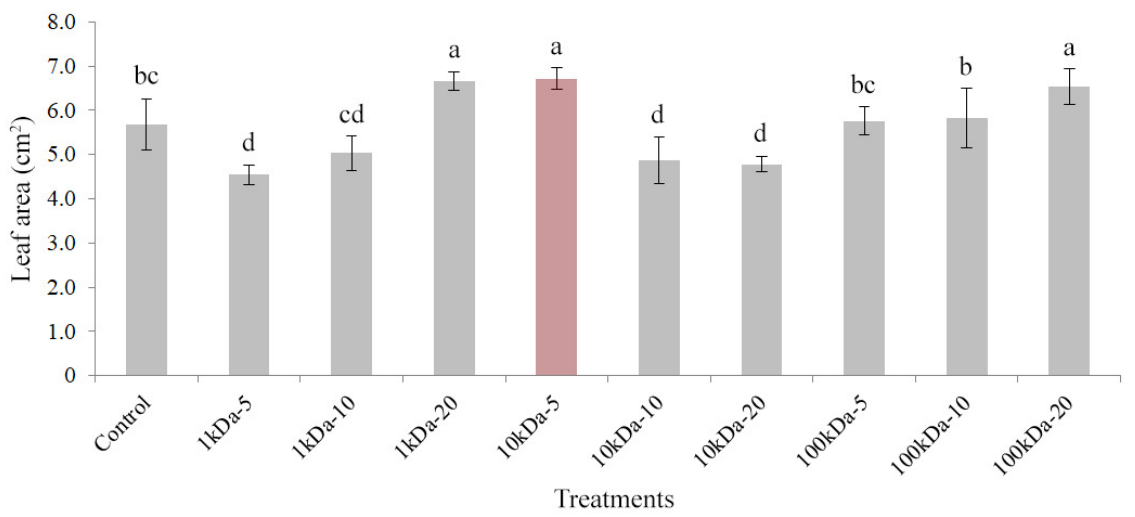

Figure 3. Effects of chitosan at 1,10 , and $100 \mathrm{kDa}$ molecular weights on the leaf area in arugula The treatments are represented as "chitosan's MW - concentration $\left(\mathrm{mg} \mathrm{L}^{-1}\right)$ ". The bars with the same superscript letters are not significantly different by Duncan's multiple range test $(\mathrm{p}<0.05)$

\section{Effect of chitosan on root development}

At the end of the cultivation period, the most elongate roots $(12.87 \pm 0.60 \mathrm{~cm})$ were found from the plants grown in the control group, while the $1 \mathrm{kDa}$ chitosan treatment at $5 \mathrm{mg} \mathrm{L}^{-1}$ significantly reduced the root growth and gave the shortest root length $(7.49 \pm 0.43 \mathrm{~cm})$. All the chitosan treatments tested decreased the root elongation regardless of their molecular weight and concentration in the irrigation water (Figure 4). The 1,10 , and $100 \mathrm{kDa}$ chitosan treatments at 20,5 , and $20 \mathrm{mg} \mathrm{L}^{-1}$, respectively, gave the statistically the same results. Although they showed reduced root growth compared to the control, the treatments 1 and $100 \mathrm{kDa}$ chitosan slightly increased the root length, whereas $10 \mathrm{kDa}$ chitosan treatments led to a decrease in the same parameter concentration-dependent trend.

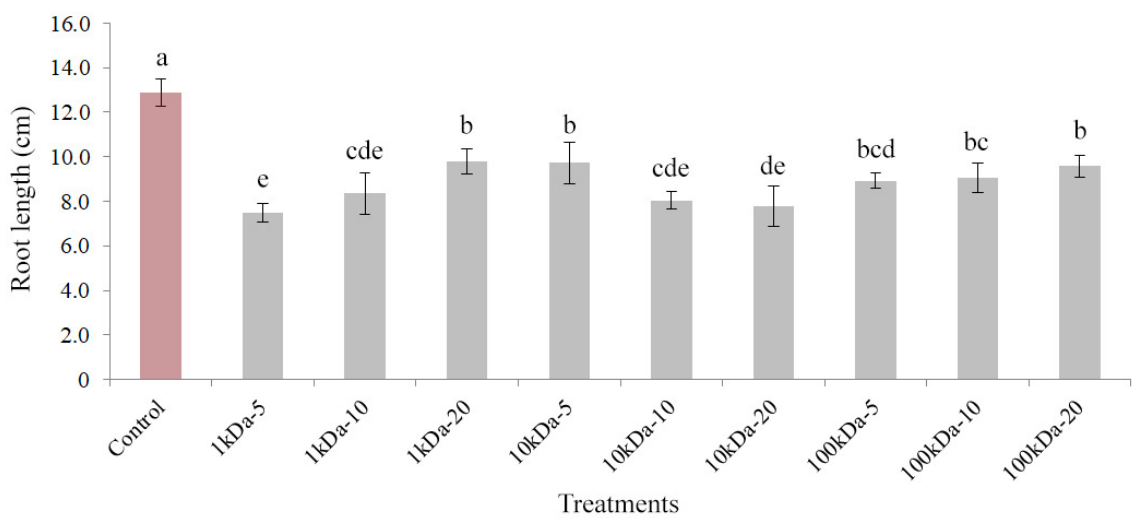

Figure 4. Effects of chitosan at 1,10 , and $100 \mathrm{kDa}$ molecular weights on the root elongation in arugula The treatments are represented as "chitosan's MW - concentration $\left(\mathrm{mg} \mathrm{L}^{-1}\right)$ ". The bars with the same superscript letters are not significantly different by Duncan's multiple range test $(\mathrm{p}<0.05)$ 


\section{Effect of chitosan on photosynthetic pigment contents}

Chlorophyll contents of arugula plants were not found different after chitosan treatments. All the treatments induced statistically the same chlorophyll a content in the plants. The plants from the control group had a chlorophyll a content of $3.28 \pm 0.17 \mu \mathrm{g} \mathrm{ml}^{-1}$. The highest chlorophyll a content $\left(3.33 \pm 0.10 \mu \mathrm{g} \mathrm{ml}^{-1}\right)$ was found from the leaves of arugula plants irrigated with the solution having $100 \mathrm{kDa}$ chitosan at $20 \mathrm{mg} \mathrm{L}^{-1}$ concentration, while the leaves gave the minimum chlorophyll a content $\left(3.19 \pm 0.06 \mu \mathrm{g} \mathrm{ml}^{-1}\right)$ after $10 \mathrm{kDa}$ chitosan treatment at $20 \mathrm{mg} \mathrm{L}^{-1}$ (Figure 5).

All the chitosan treatments increased the chlorophyll $\mathrm{b}$ and carotenoid contents. The leaves harvested from the control group had the minimum chlorophyll $b$ and carotenoid contents of $1.59 \pm 0.18$ and $1.24 \pm$ $0.11 \mu \mathrm{g} \mathrm{ml}^{-1}$, respectively (Figure 5). The maximum chlorophyll b content $\left(1.85 \pm 0.02 \mu \mathrm{g} \mathrm{ml}^{-1}\right)$ was found from the leaves of arugula plants irrigated with the solution having $10 \mathrm{kDa}$ chitosan at $20 \mathrm{mg} \mathrm{L}^{-1}$, while the leaves taken from the plants treated with $100 \mathrm{kDa}$ chitosan at $10 \mathrm{mg} \mathrm{L}^{-1}$ gave the maximum carotenoid content $(1.59$ $\left.\pm 0.06 \mu \mathrm{g} \mathrm{ml}^{-1}\right)$.

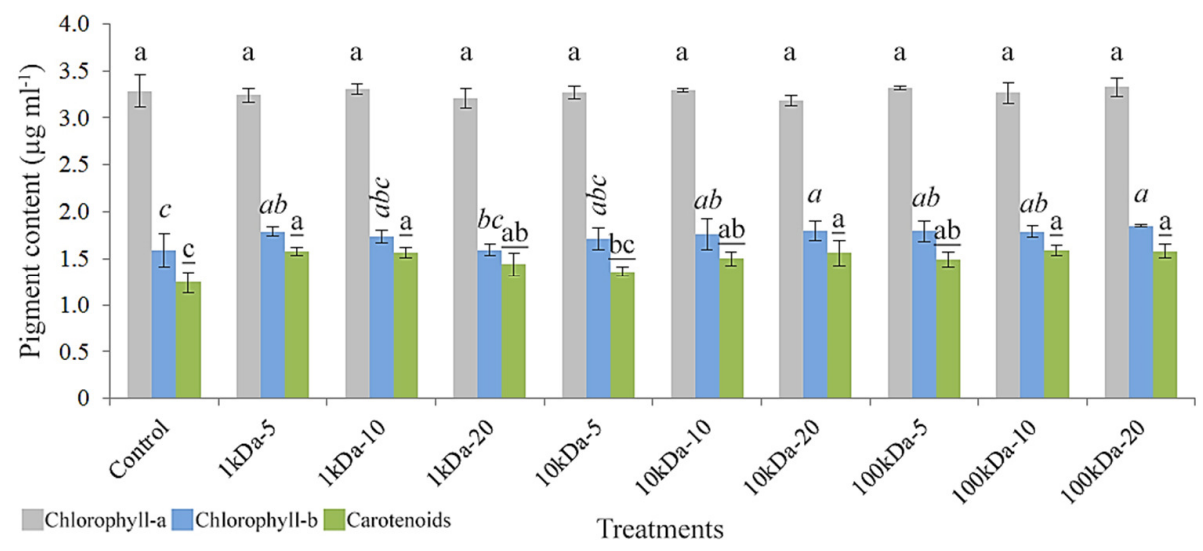

Figure 5. Effects of chitosan at 1,10, and $100 \mathrm{kDa}$ molecular weights on the photosynthetic pigment contents in leaves of arugula

The treatments are represented as "chitosan's MW - concentration $\left(\mathrm{mg} \mathrm{L}^{-1}\right)$ ". The bars with the same-style superscript letters are not significantly different by Duncan's multiple range test $(\mathrm{p}<0.05)$

\section{Effect of chitosan on individual phenolic substance pattern}

Individual phenolic substance contents of the leaves harvested from control and chitosan-treated (10 $\mathrm{kDa}$ at $5 \mathrm{mg} \mathrm{L}^{-1}$ ) plants were compared. After the treatment, the gallic acid content in the arugula leaves significantly increased $($ sig. $=0.00)$. However, catechin content from the control group was found to decrease after the treatment. Chlorogenic acid contents remained the same both in control and in the treated plants. pCoumaric acid content slightly increased after the treatment; however, it was not statistically significant. Rutin and apigenin contents in the control group leaves increased significantly (sig. $=0.04$ and 0.02 ) after the treatment (Figure 6). Ferulic acid and quercetin contents were below the detection limit.

\section{Hierarchical cluster analysis}

The best treatment in means of induction of foliar growth was found $10 \mathrm{kDa}$ chitosan at $5 \mathrm{mg} \mathrm{L}^{-1}$. The most efficient treatments $10 \mathrm{kDa}$ and 100 chitosan at 5 and $20 \mathrm{mg} \mathrm{L}^{-1}$, respectively, were grouped in the same cluster with the control (Figure 7). However, the other promising treatment $1 \mathrm{kDa}$ chitosan at $20 \mathrm{mg} \mathrm{L}^{-1}$ was found in another cluster but next to the treatment $100 \mathrm{kDa}$ at $20 \mathrm{mg} \mathrm{L}^{-1}$. The chitosan treatments $1 \mathrm{kDa}$ at 5 and $10 \mathrm{mg} \mathrm{L}^{-1}$, and $10 \mathrm{kDa}$ at 10 and $20 \mathrm{mg} \mathrm{L}^{-1}$ were also found in the same cluster, which was distant from the control. 


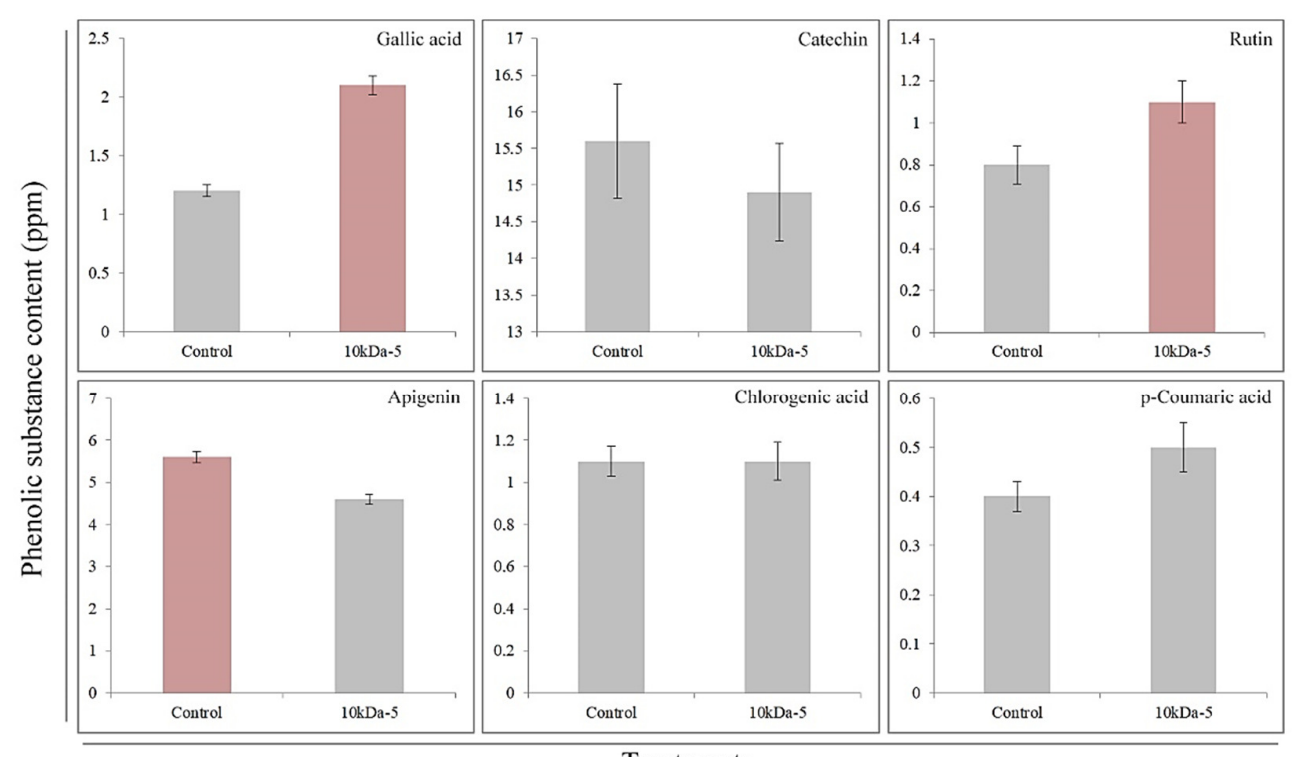

Treatments

Figure 6. Effects of $10 \mathrm{kDa}$ chitosan at $5 \mathrm{mg} \mathrm{L}^{-1}$ on the individual phenolic substance contents in leaves of arugula

The graphs with red bars indicate statistically significant changes according to the independent samples $t$-test $(\mathrm{p}<$ $0.05)$

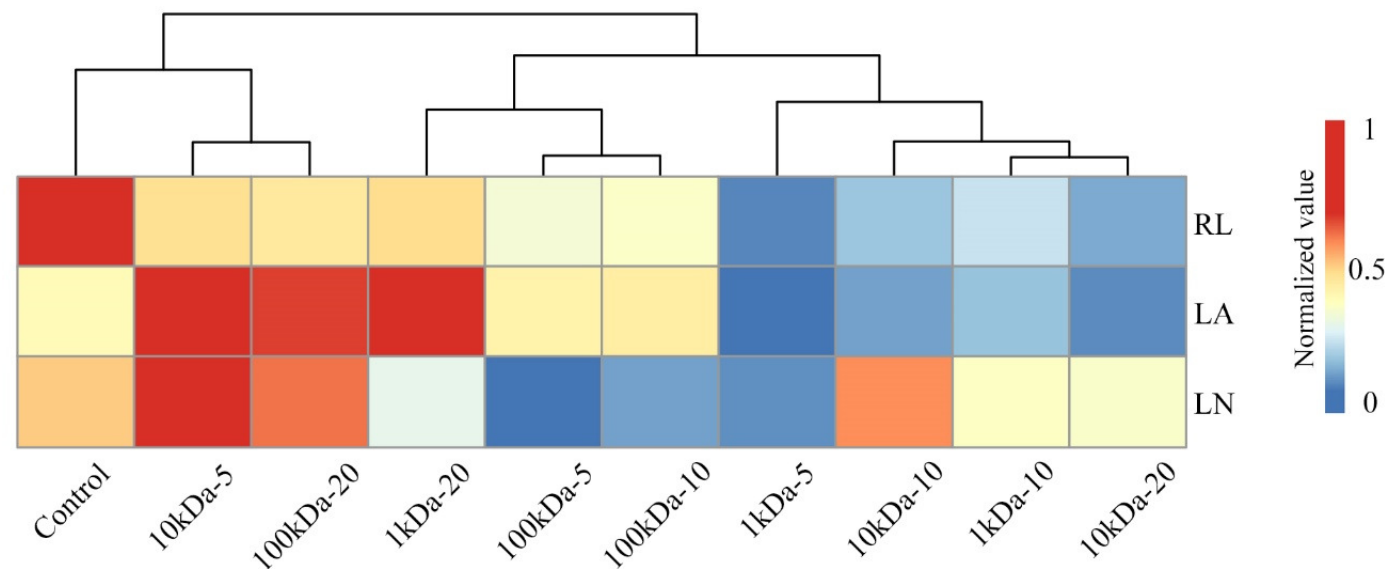

Figure 7. Hierarchical clustering heat map-based comparison of the normalized developmental data from arugula. Leaf number (LN), Leaf area (LA), Root length (RL)

The treatments are represented as "chitosan's MW - concentration $\left(\mathrm{mg} \mathrm{L}^{-1}\right)$ "

\section{Discussion}

Arugula has been employed as a research plant in studies, including the recent ones that aimed to investigate light color and intensity on the plant's growth (Johnson et al., 2020) to understand selenium tolerance of the species (Santiago et al., 2020), and to increase yield through foliar zinc (Rugeles-Reyes et al., 2019), sulfur, and tyrosine treatments (Al-Mohammad and Al-Taey, 2019). However, the studies explaining the effects of chitosan treatment on Eruca vesicaria ssp. sativa are quite limited. Youssef (2018) placed the arugula seeds on chitosan powder-coated cotton pads and left them for germination in one of these studies. The author found an increase in the germination rate of chitosan-treated arugula seeds while reporting the 
minimized availability of $\mathrm{Cu}, \mathrm{Zn}, \mathrm{Mn}, \mathrm{Ni}, \mathrm{F}$, and $\mathrm{Al}$ in the plants after chitosan treatment. However, chitosan used in the study was not characterized; thus, it would be labor intensive to conduct the same method for middle- or large-scale production. Therefore, chitosan application by adding it to irrigation water or by foliar spraying would be more practical.

Leaf production and leaf area expansion in leafy vegetables, especially those sold in bundles, are important parameters that affect the plants' quality and consumers' choice. Therefore, these parameters would play a role in the commercialization of arugula. In the current study, only $10 \mathrm{kDa}$ chitosan treatment at $5 \mathrm{mg}$ $\mathrm{L}^{-1}$ triggered leaf production significantly. However, chitosan oligomers' ability to trigger leaf production has been demonstrated in tomato plants (Monirul et al., 2018). The authors found the highest leaf number in the tomato plants treated with chitosan oligomers at $100 \mathrm{mg} \mathrm{L}^{-1}$. Mondal et al. (2016) also reported an increase in leaf production after spraying uncharacterized chitosan at $75 \mathrm{mg} \mathrm{L}^{-1}$ onto tomato plants. A similar finding has been reported from the strawberry plant after foliar chitosan treatments between 125 and $1000 \mathrm{mg} \mathrm{L}^{-1}$ concentrations (Rahman et al., 2018). The authors used commercially available, low-viscosity chitosan with a higher DA than 75\%. In another study, Theerakarunwong and Phothi (2016) tested the effects of $50 \mathrm{kDa}$ chitosan on ten rice cultivars, and the authors found chitosan treatments triggered leaf production in most of the cultivars tested. Considering the reports summarized above, our study suggested that $10 \mathrm{kDa}$ chitosan at a low concentration might be enough to trigger leaf production in arugula. The beneficial effects of chitosan in plants' vegetative growth might be attributed to the regulation of photosynthesis, carbohydrate metabolism, and cell redox homeostasis through a gene expression network between the nucleus and chloroplast (Chamnanmanoontham et al., 2015). However, further molecular studies should be conducted to reveal the exact mechanism behind chitosan's success in arugula's leaf production.

Besides the leaf number, leaf area in such vegetables like arugula is considered an indicator of yield. Thus, expanded leaves with larger leaf areas would be beneficial in the commercialization of most leafy vegetables. The lowest concentration of $10 \mathrm{kDa}$ chitosan was the best treatment for leaf expansion in arugula in the current study. Also, close results were recorded from 1 and $100 \mathrm{kDa}$ chitosan treatments at $20 \mathrm{mg} \mathrm{L}^{-1}$. These treatments are also considered to be beneficial to leaf expansion in arugula. However, their concentrations are considerably higher than the optimal $10 \mathrm{kDa}$ chitosan treatment, leading to an increase in arugula's cultivation cost. In a study, Dar et al. (2015) reported an increase in leaf area after treating fenugreek plant with chitosan oligomers (obtained through gamma radiation) at 40,80 , and $120 \mathrm{mg} \mathrm{L}^{-1}$. A similar increase in the parameter was reported from mungbean by Mondal et al. (2013), who treated the plants with uncharacterized chitosan spray at 25 and $50 \mathrm{mg} \mathrm{L}^{-1}$. In another study, Boonlertnirun et al. (2011) treated corn seedlings with a chitosan oligomer with DA of $10 \%$ at $80 \mathrm{mg} \mathrm{L}^{-1}$. The authors reported significant increases in leaf area, waxy corn yield, and leaf greenness parameters suggesting that chitosan might be used to reduce chemical fertilizer use in corn cultivation. Darvill et al. (1992) attributed chitosan oligomers' activity in triggering plants' defense responses and stimulating the growth to plants' recognition of the oligomers. However, high molecular weight chitosan treatment also increased arugula's leaf area in our study. In this context, Barber et al. (1989) reported that chitosan monomer, dimer, and trimer might not might induce lignification, whereas chitin oligomers may elicit lignification in wounded wheat leaves. Therefore, chitosan's function may differ according to its structure and plant species, and the increased lignification in leaves might result in better growth.

Plant root development in the cultivation of leafy vegetables directly affects neither commercialization of the plants nor consumers' choice. However, the root system extends deeply into the soil and directly affects the nutrient uptake. Also, as the chitosan tested in the current study was given through irrigation but not by foliar spraying, the arugula's roots were the primary organ exposed to the treatments. Thus, direct effects of chitosan could be seen in the root development in such studies. In our study, regardless of their concentration and molecular weight, chitosan treatments restricted the root development in arugula. Chitosan treatments have been shown to decrease root development in tissue culture of morning glory where the plant was subjected to chitosan oligomers and polymers for $30 \mathrm{~d}$ (Acemi et al., 2018). However, similar treatments for more prolonged periods were reported to induce rooting and micro tuber formation in long-lipped Serapias (Acemi, 
2020a). The favorable effects of chitosan oligomers with DA of $<10 \%$ have been shown on root development in mentha (Ahmad et al., 2017) and lemongrass (Jaleel et al., 2017) after foliar spraying. When applied directly to the soil, these results indicated that chitosan treatments might arrest root development, whereas chitosan foliar application might support root development. This chitosan property might be explained by its nitrogencontaining nature that enables a gradual penetration in the soil, thereby making it remain active for more extended periods (Dar et al., 2015).

The consumers' choice to select leafy vegetables might also be affected by a possible differentiation in the plant's look and color. In our study, the production of chlorophyll a in arugula leaves was not significantly different based on the application of chitosans. However, a significant increase in chlorophyll b and carotenoid contents was found after the treatments. Enhanced chlorophyll and carotenoid contents were also found in potato plants under drought stress after foliar chitosan and oligo-chitosan treatments (Muley et al., 2019). In another study that the effects of chitosan oligomers and polymer were tested in morning glory plants, the authors found both chitosan variants significantly induced the production of chlorophyll a, b, and carotenoids (Kiran Acemi and Acemi, 2019). The increase in the photosynthetic pigment contents in plants might be due to enhanced stomatal conductance, transpiration rate, and cell size and number after chitosan treatments (Khan et al., 2002). The high photosynthetic performance may indirectly contribute to organic matter accumulation in plants (Zeng and Luo, 2012). Also, Muley et al. (2019) indicated that chitosan might have a role in elevating chloroplast numbers per cell and chlorophyll synthesis since it provides an extra amino group.

In light of the above-described results, the $10 \mathrm{kDa}$ chitosan treatment at $5 \mathrm{mg} \mathrm{L}^{-1}$ was the best treatment performed in the means of leaf production and expansion to improve foliar growth arugula. Therefore, the contents of individual phenolic substances were quantified through reversed-phase HPLC (RP-HPLC). It was shown that chitosan treatment might also alter the phenolic substance production in plants. This property of chitosan has also been demonstrated on Camellia sinensis (Srisornkompon et al., 2014). Therefore, chitosan might also be a biostimulant for phenolics production in plants.

\section{Conclusions}

The current study suggested that direct chitosan application into the soil restricts root development in arugula; however, it enhances foliar growth, which is advantageous since only leaves of arugula are commercially significant and edible. Chitosan with a molecular weight of $10 \mathrm{kDa}$ at a low concentration should be preferred for improved foliar growth in arugula cultivation. Also, this study showed that chitosan treatment might alter phenolic substance production in leafy vegetables. Consequently, chitosan use as an organic and natural biostimulant in horticultural crop production could be a better option than synthetic growth stimulants.

\section{Authors' Contributions}

Conceptualization: AA; Data curation: AA, EGP, MÇ; Formal analysis: AA; Investigation: EGP, MÇ, ED, BP; Methodology: AA; Resources: FÖ; Visualization: AA; Writing - original draft: AA; Writing - review and editing: AA, FÖ. All authors read and approved the final manuscript.

\section{Acknowledgements}

We are grateful to Nour Eddine El Gueddari of the University of Münster, Münster, Germany, who supplied the chitosan samples. Nour Eddine El Gueddari was deceased on February 8, 2018. This study was supported by the Scientific Research Unit of Kocaeli University, Turkey, under the project AR-GE-1282. 


\section{Conflict of Interests}

The authors declare that there are no conflicts of interest related to this article.

\section{References}

Acemi A, Bayrak B, Çakir M, Demiryürek E, Gün E, El Gueddari NE, Özen F (2018). Comparative analysis of the effects of chitosan and common plant growth regulators on in vitro propagation of Ipomoea purpurea (L.) Roth from nodal explants. In Vitro Cellular and Developmental Biology - Plant 54:537-544. https://doi.org/10.1007/s11627-018-9915-0

Acemi A (2020a). Chitosan versus plant growth regulators: a comparative analysis of their effects on in vitro development of Serapias vomeracea (Burm.f.) Briq. Plant Cell, Tissue and Organ Culture 141:327-338. https://doi.org/10.1007/s11240-020-01789-3

Acemi A (2020b). Polymerization degree of chitosan affects structural and compositional changes in the cell walls, membrane lipids, and proteins in the leaves of Ipomoea purpurea: An FT-IR spectroscopy study. International Journal of Biological Macromolecules 162:715-722. https://doi.org/10.1016/j.ijbiomac.2020.06.171

Ahmad B, Khan MMA, Jaleel H, Sadiq Y, Shabbir A, Uddin M (2017). Exogenously sourced $\gamma$-irradiated chitosanmediated regulation of growth, physiology, quality attributes and yield in Mentha piperita L. Turkish Journal of Biology 41(2):388-401. https://doi.org/10.3906/biy-1608-64

Al-Mohammad MHS, Al-Taey DKA (2019). Effect of tyrosine and sulfur on growth, yield and antioxidant compounds in arugula leaves and seeds. Research on Crops 20(1):116-120. https://doi.org/10.31830/2348-7542.2019.016

Barber MS, Bertram RE, Ride JP (1989). Chitin oligosaccharides elicit lignification in wounded wheat leaves. Physiological and Molecular Plant Pathology 34:3-12. https://doi.org/10.1016/0885-5765(89)90012-X

Benke K, Tomkins B (2018). Future food-production systems: vertical farming and controlled environment agriculture. Sustainability: Science, Practice and Policy 13(1):13-26. https://doi.org/10.1080/15487733.2017.1394054

Boonlertnirun S, Suvannasara R, Promsomboon P, Boonlertnirun K (2011). Application of chitosan for reducing chemical fertilizer uses in waxy corn growing. Thai Journal of Agricultural Science 44(5):22-28.

Chamnanmanoontham N, Pongprayoon W, Pichayangkura R, Roytrakul S, Chadchawan S (2015). Chitosan enhances rice seedling growth via gene expression network between nucleus and chloroplast. Plant Growth Regulation 75:101-114. https://doi.org/10.1007/s10725-014-9935-7

Dar TA, Uddin M, Khan MMA, Ali A, Mir SR, Varshney L (2015). Effect of Co-60 gamma irradiated chitosan and phosphorus fertilizer on growth, yield and trigonelline content of Trigonella foenum-graecum L. Journal of Radiation Research and Applied Sciences 8(3):446-458. https://doi.org/10.1016/j.jrras.2015.03.008

Darvill A, Augur C, Bergmann C, Carlson RW, Cheong J-J, Eberhard S, ... Albersheim P (1992). Oligosaccharinsoligosaccharides that regulate growth, development and defence responses in plants. Glycobiology 2(3):181-198. https://doi.org/10.1093/glycob/2.3.181

Jaleel H, Khan MMA, Ahmad B, Shabbir A, Sadiq Y, Uddin M, Varshney L (2017). Essential oil and citral production in field-grown lemongrass in response to gamma-irradiated chitosan. Journal of Herbs, Spices and Medicinal Plants 23(4):378-392. https://doi.org/10.1080/10496475.2017.1349702

Johnson RE, Kong Y, Zheng Y (2020). Elongation growth mediated by blue light varies with light intensities and plant species: A comparison with red light in arugula and mustard seedlings. Environmental and Experimental Botany 169:103898. https://doi.org/10.1016/j.envexpbot.2019.103898

Khan WM, Prithiviraj B, Smiyh DL (2002). Effect of foliar application of chitin and chitosan oligosaccharides on photosynthesis of maize and soybean. Photosynthetica 40:621-624. https://doi.org/10.1023/A:1024320606812

Kiran Acemi R, Acemi A (2019). Polymerization degree-dependent changes in the effects of in vitro chitosan treatments on photosynthetic pigment, protein, and dry matter contents of Ipomoea purpurea. EuroBiotech Journal 3(4):197-202. https://doi.org/10.2478/ebtj-2019-0024

Kıran Acemi R, Acemi A, Çakır M, Gün Polat E, Özen F (2020). Preliminary screening the antioxidant potential of in vitro-propagated Amsonia orientalis. An example to sustainable use of rare medicinal plants in pharmaceutical studies. Sustainable Chemistry and Pharmacy 17:100302. https://doi.org/10.1016/j.scp.2020.100302 
Ladaru G-R, Ilie DM, Diaconeasa MC, Petre IL, Marin F, Lazar V (2020). Influencing factors of a sustainable vegetable choice. The Romanian consumers' case. Sustainability 12:9991. https://doi.org/10.3390/su12239991

Lichtenthaler H (1987). Chlorophylls and carotenoids: pigments of photosynthetic biomembranes. Methods in Enzymology 148:350-382. https://doi.org/10.1016/0076-6879(87)48036-1

Metsalu T, Vilo J (2015). ClustVis: a web tool for visualizing clustering of multivariate data using principal component analysis and heatmap. Nucleic Acids Research 43(W1):W566-W570. https://doi.org/10.1093/nar/gkv468

Mondal M, Puteh AB, Dafader NC (2016). Foliar application of chitosan improved morpho-physiological attributes and yield in summer tomato (Solanum lycopersicum). Pakistan Journal of Agricultural Sciences 53(2):339-344. https://doi.org/10.21162/PAKJAS/16.2011

Mondal MMA, Malek MA, Puteh AB, Ismail MR (2013). Foliar application of chitosan on growth and yield attributes of mungbean (Vigna radiata (L.) Wilczek). Bangladesh Journal of Botany 42(1):179-183. https://doi.org/10.3329/bjb.v42i1.15910

Mondal MMA, Rana IK, Dafader NC, Haque ME (2011). Effect of foliar application of chitosan on growth and yield in Indian spinach. Journal of Agroforestry and Environment 5(1):99-102.

Monirul IM, Humayun KM, Mamun ANK, Monirul I, Pronabananda D (2018). Studies on yield and yield attributes in tomato and chilli using foliar application of oligo-chitosan. GSC Biological and Pharmaceutical Sciences 3(3):20-28. https://doi.org/10.30574/gscbps.2018.3.3.0038

Morales M, Janick J (2002). Arugula: A promising specialty leaf vegetable. In: Janick J, Whipkey A (Eds). Trends in New Crops and New Uses. ASHS Press, Alexandria, VA, USA, pp 418-423.

Muley AB, Shingote PR, Patil AP, Dalvi SG, Suprasanna P (2019). Gamma radiation degradation of chitosan for application in growth promotion and induction of stress tolerance in potato (Solanum tuberosum L.). Carbohydrate Polymers 210:289-301. https://doi.org/10.1016/j.carbpol.2019.01.056

Muxika A, Etxabide A, Uranga J, Guerrero P, de la Caba K (2017). Chitosan as a bioactive polymer: Processing, properties and applications. International Journal of Biological Macromolecules 105(2):1358-1368. https://doi.org/10.1016/j.ijbiomac.2017.07.087

Nge KL, New N, Chandrkrachang S, Stevens WF (2006). Chitosan as a growth stimulator in orchid tissue culture. Plant Science 170(6):1185-1190. https://doi.org/10.1016/j.plantsci.2006.02.006

Pandey SK, Singh H (2011). A simple, cost-effective method for leaf area estimation. Journal of Botany 2011:658240. https://doi.org/10.1155/2011/658240

Rahman M, Mukta JA, Sabir AA, Gupta DR, Mohi-Ud-Din M, Hasanuzzaman M, ... Islam T (2018). Chitosan biopolymer promotes yield and stimulates accumulation of antioxidants in strawberry fruit. PLoS ONE 13(9):e0203769. https://doi.org/10.1371/journal.pone.0203769

Romanazzi G, Feliziani E, Baños SB, Sivakumar D (2015). Shelf life extension of fresh fruit and vegetables by chitosan treatment. Critical Reviews in Food Science and Nutrition 57(3):579-601. https://doi.org/10.1080/10408398.2014.900474

Rugeles-Reyes SM, Cecílio Filho AB, López Aguilar MA, Silva PHS (2019). Foliar application of zinc in the agronomic biofortification of arugula. Food Science and Technology 39(4):1011-1017. https://doi.org/10.1590/fst.12318

Sahariah P, Másson M (2017). Antimicrobial chitosan and chitosan derivatives: A review of the structure-activity relationship. Biomacromolecules 18(11):3846-3868. https://doi.org/10.1021/acs.biomac.7b01058

Santiago FEM, Silva MLS, Cardoso AAS, Duan Y, Guilherme LRG, Liu J, Li L (2020). Biochemical basis of differential selenium tolerance in arugula (Eruca sativa Mill.) and lettuce (Lactuca sativa L.). Plant Physiology and Biochemistry 157:328-338. https://doi.org/10.1016/j.plaphy.2020.11.001

Srisornkompon P, Pichyangkura R, Chadchawan S (2014). Chitosan increased phenolic compound contents in tea (Camellia sinensis) leaves by pre- and post-treatments. Journal of Chitin and Chitosan Science 2:1-6. https://doi.org/10.1166/jcc.2014.1056

Theerakarunwong CD, Phothi R (2016). Physiological and photosynthesis enhancement of Thai rice (Oryza sativa L.) cultivars by chitosan. NU. International Journal of Science 13(1):37-49.

Uthairatanakij A, Teixeira da Silva JA, Obsuwan K (2007). Chitosan for improving orchid production and quality. Orchid Science and Biotechnology 1(1):1-5.

Youssef NH (2018). Assessment of aflatoxins produced by certain Aspergilla in heavy metals contaminated soil treated with commercial chitosan. International Journal of Current Research 10(7):71562-71567. https://doi.org/10.24941/ijcr.30642.07.2018 
Zeng D, Luo X (2012). Physiological effects of chitosan coating on wheat growth and activities of protective enzyme with drought tolerance. Open Journal of Soil Science 2:282-288. https://doi.org/10.4236/ojss.2012.23034

OPEN ACCESS

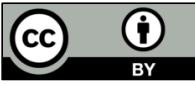

The journal offers free, immediate, and unrestricted access to peer-reviewed research and scholarly work. Users are allowed to read, download, copy, distribute, print, search, or link to the full texts of the articles, or use them for any other lawful purpose, without asking prior permission from the publisher or the author.

License - Articles published in Notulae Botanicae Horti Agrobotanici Cluj-Napoca are Open-Access, distributed under the terms and conditions of the Creative Commons Attribution (CC BY 4.0) License.

(C) Articles by the authors; UASVM, Cluj-Napoca, Romania. The journal allows the author(s) to hold the copyright/to retain publishing rights without restriction. 